\title{
Corporate Governance and Audit Quality in Nigeria
}

\author{
Stanley Ogoun*, Owota George Perelayefa \\ Department of Accountancy, Niger Delta University, Wilberforce Island, Nigeria \\ Email: *stanleyogoun@ndu.edu.ng, ^stanleyogoun@gmail.com, georgeowota@ndu.edu.ng, owotageorge@gmail.com
}

How to cite this paper: Ogoun, S., \& Perelayefa, O. G. (2020). Corporate Governance and Audit Quality in Nigeria. American Journal of Industrial and Business Management, 10, 250-261.

https://doi.org/10.4236/ajibm.2020.102016

Received: December 31, 2019

Accepted: February 10, 2020

Published: February 13, 2020

Copyright $\odot 2020$ by author(s) and Scientific Research Publishing Inc. This work is licensed under the Creative Commons Attribution International License (CC BY 4.0).

http://creativecommons.org/licenses/by/4.0/

(c) (i) Open Access

\begin{abstract}
The motivation for this study emanates from the perception that the production of a quality audit report fosters confidence in financial reports by the issuers of those reports. The paper examines specifically the role of corporate governance in determining the audit quality of firms. The study utilised 71 non-financial firms for the periods 2008 to 2015 . Audit quality was measured using a dummy variable of " 1 " and " 0 ", with 1 representing the use of a big four auditor by the firm and 0 otherwise. Corporate governance was proxy with board independence measured using the ratio of non-executive directors to total directors. The data collected was analysed using the binary regression analysis. The findings reveal that board independence is negatively related to audit quality. The study highlights the importance of having proper mix of competences on the board. The study recommends that the composition of non-executive directors as members of the board should be sustained and improved upon.
\end{abstract}

\section{Keywords}

Accounting, Auditing, Binary Regression, Corporate Governance, Audit Quality

\section{Introduction}

The prevalence of fraud, excessive earnings management and other financial crimes in the country has to a great extent placed doubt in the financial statements, as well as the ability of these statements to perform their requisite functions. In the light of the cost implications of frauds to the business, it has become essential to develop strategies that could help detect and even prevent this business fraud (Akinjobi \& Omowumi, 2010). The devastation left behind after every act of fraud is better imagined than experienced. Some have become paranoid and in- 
vestment adverse because of the bitter experience of fraudulent dealing tables as victims of the act. While, the beneficiaries of the act goes home smiling if not sanctioned and gravitates to higher schemes of fraud.

Quite unfortunately, the prevalent nature of our modern day economic ventures are such that the owners cannot handle every aspect of the operations of their enterprises even at the micro, small and medium scale enterprises domain. Thus, requiring employees to handle various aspects of the work. This delegation which informs the stewardship theory paradigm is now a constant with its attendant human problem of greed. All stakeholders in the globe are concerned about the need to address this malady with a view to eliminating its occurrence. Corporate Governance (CG) is one of the institutional reform measures initiated aimed at not just addressing the issue of agency cost, but also ensuring proper management of economic institutions. The acceptance of this recipe globally is evident in the number of national corporate governance codes and reports that have been issued by a number of countries (Rossouw, 2005). CG refers to the way companies are directed and controlled. A primary concern is the likelihood of a deviation in the objectives of corporate managers from those of shareholders due to the costs involved in monitoring managerial behaviour (O'Sullivan, 2000). The board of directors is a key component of the internal CG mechanism of the firm, that is designed to monitor the conduct of the firm's business (Fama, 1980). The board of directors is particularly important in developing economies, characterised by relatively weak governance mechanisms and institutions, such as market for control, financial markets, regulators, monitoring and legal system (Ujunwa, Salami, \& Umar, 2013). Evidently, the effective deployment of CG tools has resulted in recorded improvements in the management business ventures in most climes.

Meanwhile, prior to the emphasis on CG and after, audit has been relied upon and continues to be relied upon as a means of attestation to the credibility of reported earnings. Third parties rely on the audit information gateway to evaluate the authenticity of the reported earnings. However, the resulting scandals have cast a serious shadow of doubt on the reliability of audit reports, thus bringing to the fore the issue of quality. In this regard, it has been advocated by audit market scholars that the objective of an audit assignment is to produce a quality report that can only be achieved through strict adherence to the principles of high audit quality (DeAngelo, 1981). DeAngelo (1981), one of the pioneer works on audit quality defined the concept as the market-assessed joint probability that a given auditor will both detect material misstatements in the client's financial statement and report the material misstatements. This outcome is dependent on the auditor's professional conduct, which includes factors such as objectivity, due professionalism and conflict of interest (Mgbame, Eragbhe, \& Osazuwa, 2012). Further emphasising the role of auditing, it provides the needed assurance for investors who have only the audited financial statements to provide information on how the company has fared. Auditing reduces the information asymmetry on accounting numbers, and minimizes the residual loss resulting from manager's 
opportunism in the financial reporting process (Adeyemi \& Fagbemi, 2010).

The motivation for this study emanates from the perception that the production of a quality audit report fosters confidence in financial reports by the users of those reports. Investors in particular tend to place better trust in financial statements that are audited; as the expected independence of the auditor boosts the assurance that important investment decisions can be made on the thrust of those statements (Onwuchekwa, Erah, \& Izedonmi, 2012). The increased confidence of these sets of financial users tends to attract the inflow of capital which has the long-run effect of creating growth and development in the business environment (Adeyemi \& Fagbemi, 2010). Therefore, inefficiencies on the part of management could lead to poor financial reporting. Financial statements originating from such a system do not show the true state of affairs and financial position of the organisation and hence, could jeopardize the decisions of prospective investors.

Prior studies on audit quality have examined a number of factors that predict audit quality. For instance auditor related factors such as audit tenure, audit firm size, auditor rotation (Barbara, Broady, \& Pany, 2006; Onwuchekwa et al., 2012). Others have examined corporate governance factors such as the ownership structure, board independence (Enofe, Mgbame, Aderin, \& Ehi-Oshio, 2013; Adeyemi \& Fagbemi, 2010; O'Sullivan, 2000). This study examines specifically the role of CG in determining audit quality of firms. It contributes to the existing literature as it explores specifically the role of board independence in determining audit quality in Nigeria where the limited evidence has been inconsistent. It also uses a large firm-year observation which also improves the statistical relevance of the result sample compared to prior studies in Nigeria that only used a small observation (Enofe et al., 2013). In addition, the study makes use of binary regression which has been found appropriate when the dependent variable is a binary measure (Greene, 2002; Gujurati, 2003).

The rest of the paper is divided into five sections: section two examines the literature review; section three focusses on the methodology; section four presents the analysis and discussions and lastly section five presents the conclusion and recommendations.

\section{Literature Review}

\subsection{Overview of Audit Quality}

Auditing is the activity carried on by the auditor when he verifies accounting data determines the accuracy and reliability of accounting statements, and then reports on his findings (Omoye \& Aronmwan, 2013). It is basically an activity carried on by an independent person with the aim of reporting on the true and fairness of financial statements (Millichamp, 1994). Auditing of financial statement is the systematic process of objectively obtaining and evaluating evidence regarding assertions about economic actions and events to ascertain the degree of correspondence between these assertions and established criteria and com- 
municating the results to interested users (Rittenberg, Johnstone, \& Gramling, 2012). In essence auditing is used to provide the needed reasonable assurance for financial statement users who rely on audited financial statements.

The issue of audit quality has been widely debated in audit market research. Researchers have failed to reach a consensus on an appropriate definition of the concept not to mention an ideal measurement. Various organisational stakeholders such as auditors, investors and regulators indeed have different views as to what constitutes audit quality. One of the pioneering authors on audit quality, type of indicators one might use to assess audit quality DeAngelo (1981) defined audit quality as the market-assessed joint probability that the auditor discovers an anomaly in the financial statements, and reveals it. The user of financial reports may believe that high audit quality means the absence of material misstatements. The auditor conducting the audit may define high audit quality as satisfactorily completing all tasks required by the firm's audit methodology. Chan \& Wong (2002) note that audit quality, though unobservable, impacts the probability of successful detection of discrepancies between the firms' favourable report and the true quality of the project. There is a belief of users about the quality of an audit. This expectation can be broken into the actual quality and the perceived quality. Both actual quality and perceived quality have been argued as important issues in audit quality definition. Actual audit quality can be considered as the probability of reducing the risk of reporting a material misstatement in the financial statement (Palmrose, 1988). While perceived quality is the belief of financial statement users about auditor's ability to reduce the material misstatements. In this situation, greater perceived audit quality can result in investment process improvement in audited clients. Jackson, Moldrich, \& Roebuck (2007) posit that true audit quality is when the audit does not result in a type I error (a failing company being given an unqualified report) or a type II error (a non-failing company being given a qualified report).

\subsection{Review of Prior Studies}

The literature on audit quality basically have been skewed towards the examination of auditor related factors. These studies have been carried out in both developed and developing countries. Hosseinniakani, Inacio, \& Mota (2014) in a review of audit quality factors found that factors such as size, industry expertise, auditor tenure, audit fees, non-audit services and auditor reputation were found to affect audit quality significantly. From a developed country viewpoint, Barbara et al. (2006) carried out an experimental survey investigating whether auditor rotation affects the quality of audit work. They investigated the likelihood of public accountants modifying their annual report for client's departure from generally accepted accounting principles in the event of rotation. The results suggest that auditors facing rotation are more likely to modify their reports to query the deviation as contrasted to those in a situation in which a continuing relationship is expected. While, from a developing country perspective, Enofe et al. (2013) analysed the determinants of audit quality in the Nigerian business environment. 
The research empirically examined engagement and firm related characteristics such as audit tenure audit firm size, board independence and ownership structure. A regression model was used to test the significance of the variables. The result showed a positive relationship between board independence and audit quality. The weakness of the study emanates from the fact that a limited observation was used and the study only used ordinary least square regression which might not have been appropriate considering the binary measurement of the dependent variable.

Adeyemi, Okpala, \& Dabor (2012) investigated factors affecting audit quality in Nigeria. The study employed both primary and secondary data in its analysis. The study found that multiple directorship and the provision of non-audit services had a significant effect on audit quality in Nigeria. The study recommended that efforts should be made to strengthen audit quality if the quality of financial reporting were to improve. Also the study recommended that regulatory authorities should ensure that the same firm do not render audit services and offer management advisory services in the same company simultaneously. Furthermore, Omoye \& Aronmwan (2013) examined audit firm rotation and audit quality using cross-sectional pool data gathered from 15 banks in the Nigeria-banking sector for the period 2005-2011. The study found that audit firm rotation significantly affects audit quality although the effect is negative. A summary of the review shows that most of the studies on audit quality in Nigeria have focussed on auditor related factors with only limited studies looking at the governance mechanisms.

\subsection{Hypothesis Development}

The demand for external audit services originates from the agency issues, which arise out of the separation of ownership and control of firms (Jensen \& Meckling, 1976). Firms are owned by shareholders who apparently are not on ground and are absent in the running of the organisation. Professional managers control the daily activities and operations of the firms; who may or may not hold significant shareholdings in the firm (Fama, 1980). This means that the shareholders of the firm have a residual claim on the resources of the firm and that the managers of the firm will have to communicate their stewardship of the firm's resources to shareholders; normally through the periodic issue of a set of financial statements (Securities and Exchange Commission, 2000). In order to ensure that the financial information published by firms are reliable for users, it is normally required that the statements are certified by an auditor-an objective and thorough third party who performs independent examinations that give the financial statement is credibility (Enofe et al., 2013).

Fama \& Jensen (1983) have theorized that the board of directors is the best control mechanism to monitor actions of management. The study explored board independence based on the agency theory. Studies of O'Sullivan (2000) and Salleh, Stewart, \& Mason (2006) found that the proportion of non-executive directors had a significant positive impact on audit quality. They suggested that 
non-executive directors encouraged more intensive audits as a complement to their own monitoring role while the reduction in agency costs expected through significant managerial ownership resulted in a reduced need for intensive auditing.

Furthermore, a number of studies have examined the relationship between corporate governance and audit quality using various proxy for audit quality and have reported mixed results. Abdullah, Ismail, \& Jamaludin (2008) examined effective components of corporate governance and their relationship with audit quality using 655 Malaysian firms. They used big four auditors as a proxy for audit quality. Their findings showed board independence and non-financial institutional ownership having a positive significant relationship with audit quality. Similarly from Malaysia, Salleh et al. (2006) examine the effect of board composition and ethnicity on audit quality using a sample of 100 companies under the industrial sector on the Bursa Malaysia main board. The study used audit fees as a proxy for audit quality. They found that the proportion of independent directors was significantly related to audit fees, suggesting that independent directors encourage the appointment of higher quality auditors to give greater assurance to investors that company financial statements are fairly presented. From the Nigerian environment, Enofe et al. (2013) examined board independence and audit quality. They measured audit quality using the auditor independence and found a positive relationship existing between board independence and audit quality. In line with the arguments above we hypothesise a positive relationship between corporate governance and audit quality. Also, Adeyemi \& Fagbemi (2010) provided evidence on the relationship between corporate governance and audit quality. The study showed that ownership by non-executive directors has the possibility of increasing the quality of audit. The study suggested that the composition of non-executive directors as members of the board should be sustained in order to enhance audit quality. This current work is premised on further authenticating results following the revision in the code of CG for listed companies are consistent with prior studies. Thus, the current study hypothesizes that:

$\mathrm{H}_{1}$ : There is a positive relationship between corporate governance and audit quality.

\section{Methodology}

The sample was selected from only non-financial companies considering the financial companies in addition to the Securities and Exchange Code of Corporate Governance, are subjected to further regulations by the Central Bank such as Code of corporate governance for financial services companies. Also, as a result of different reporting requirements and government regulations in this sector (Gupta \& Newberry, 1997; Richardson et al., 2015; Richardson \& Lanis, 2007). The selection was based on the availability of data, as a number of annual reports were not available at the Nigerian Stock Exchange library or the company's websites. The study focussed on 71 companies for the periods 2008 to 2015 . The pe- 
riod was selected as a result of the revision in the code of corporate governance in public listed companies that occurred in 2011.

\subsection{Research Model}

The empirical analysis involves estimating the relationship between corporate governance and audit quality. We included some variables (firm size, profitability and leverage) that have been found in literature to be related to audit quality to serve as control in the model

Audit quality: $f$ (corporate governance + control variables)

$$
A U D Q=\alpha 0+\alpha_{1} C G+\alpha_{2} L E V+\alpha_{3} F S I Z E+\alpha_{4} P R O F+\varepsilon
$$

where, $A U D Q=$ audit quality; $C G=$ corporate governance; $L E V=$ leverage; $F S I Z E=$ firm size; and $P R O F=$ profitability.

\subsection{Measurement of Variables}

The measurement of variables are shown in Table 1.

\subsection{Data Analyses Techniques}

The research has a descriptive and causal undertone. The descriptive aspect describes the characteristics of the variables, while the causal relationship shows the causal effect of relationships among the variables. This was done using the binary regression analysis considering the dependent variable is measured using a dummy variable having two outcomes " 1 " and " 0 ". The study made use of Stata 13.0 econometric software.

\section{Results and Discussions}

\subsection{Descriptive Analysis}

We present the descriptive statistics of the variable used in the study in Table 2.

Table 2 highlights the description of the variables examined in the course of the study. From the table we can see that on the average about $60 \%$ of the study sample were audited by big 4 auditors which translates to having a high audit quality.

Table 1. Measurement of the variables.

\begin{tabular}{ccc}
\hline Variables & Measurement & Sources \\
\hline Audit Quality & $\begin{array}{c}\text { Dummy variable 1 if big four auditor } \\
\text { exists and 0 otherwise; }\end{array}$ & (Abdullah et al., 2008) \\
Corporate & Board independence (percentage of \\
Governance & non-executive directors to total directors); & (Kota \& Tomar, 2010) \\
Leverage & Long-term debt/equity; & (Che-Ahmad \& Osazuwa, 2015) \\
Profitability (PROF) & Profit after tax/total equity; & (Che-Ahmad \& Osazuwa, 2015) \\
Firm Size (FSIZE) & Natural log of total assets & (Wan Hussin, Che-Adam, Lode, \\
& & \& Kamardin, 2005)
\end{tabular}


Table 2. Descriptive statistics.

\begin{tabular}{ccccc}
\hline Variables & Mean & Stddev & Min & Max \\
\hline AUDQ & 0.60 & 0.49 & 0 & 1 \\
CG & 0.65 & 0.16 & 0.17 & 0.93 \\
LEV & 0.56 & 0.21 & 0.05 & 1.88 \\
FSIZE & 6.95 & 0.73 & 5.35 & 9.05 \\
PROF & 0.06 & 0.11 & -0.89 & 0.90 \\
\hline
\end{tabular}

Note: $A U D Q=$ audit quality; CG = Corporate governance; $L E V=$ leverage; FSIZE = firm size; PROF = profitability.

The mean independence of the board was 0.65 and a standard deviation of 0.16 , a minimum of 0.17 and a maximum of 0.93 . The mean was slightly higher than studies by Ajibolade \& Uwuigbe (2013), Amran \& Che Ahmad (2009) and Li \& Song (2013) that each found the mean to be $0.414,0.548$ and 0.46 respectively.

Further, the results for leverage showed a minimum value of 0.05 and a maximum value of 1.88 . The standard deviation was 0.21 and the mean was 0.56 . The result shows that on the average most of the firms are levered. The mean for the $\log$ of total assets (FSIZE) is 6.95, with a standard deviation of 0.73 . The assets amount ranges from the minimum of 5.35 to a maximum of 9.05 . The mean total assets for all companies is comparable to Amran \& Che Ahmad (2010) that reported a value of 12.73 and Che-Ahmad \& Osazuwa (2015) that reported a mean total assets of 7.65 . The average return on equity (PROF) is 0.06 , with a standard deviation of 0.11 , ranging from the minimum of -0.89 to a maximum of 0.90 . The mean ratio for profitability is comparable to study by Che-Ahmad et al. (2003) that reported a return on equity ratio of 0.29 .

\subsection{Correlation Results}

The correlation analysis of the variables is presented in Table 3. From the result of the correlation analysis, we can see that there is absence of multicollinearity among the variables. This is also confirmed when we run the variance inflation factor (VIF) as it shows there is absence of multicollinearity among the variables with a mean VIF of 1.11 which is less than the maximum acceptable value of 10 .

\subsection{Regression Results}

In estimating the audit quality model, we measure audit quality using the presence of big 4 and non-big 4 auditors. Table 4 shows the result of the estimation of the binary model.

The result of the robust binary regression is presented in Table 4 . The robust regression corrects for the problems of heteroskedasticity and autocorrelation in the data. The explained variable is audit quality. The result with adjusted $\mathrm{R}^{2}=$ 0.06 shows that $6 \%$ of the changes in the dependent variable can be explained by the explanatory variable. The adjusted $\mathrm{R}^{2}$ is similar to studies from previous studies like. The Wald $\mathrm{Ch}^{2}$ value of 29.70 indicates that the overall model is statistically significant. 
Table 3. Correlation analysis.

\begin{tabular}{cccccc}
\hline & AUDQ & CG & LEV & FSIZE & PROF \\
\hline AUDQ & 1.00 & & & & \\
CG & -0.04 & 1.00 & & & \\
LEV & -0.01 & -0.07 & 1.00 & & \\
FSIZE & 0.26 & 0.06 & 0.04 & 1.00 & \\
PROF & 0.10 & 0.04 & -0.36 & 0.17 & 1.00 \\
\hline
\end{tabular}

For variable definition see Table 2.

Table 4. Binary regression results.

\begin{tabular}{ccccc}
\hline AUDQ & Coef. & Std.err & T & $p>t$ \\
\hline CG & -0.79 & 0.59 & -1.33 & 0.09 \\
LEV & 0.02 & 0.46 & 0.05 & 0.96 \\
FSIZE & 0.76 & 0.15 & 5.02 & 0.00 \\
PROF & 1.29 & 0.97 & 1.33 & 0.09 \\
CONS & -4.40 & 1.08 & -4.08 & 0.00 \\
\hline
\end{tabular}

Notes: Adjusted $R^{2}=0.06 ;$ Wald $C h{ }^{2}=29.70 ; p=0.00 .{ }^{*}$ Significant at $10 \%$; ${ }^{\star *}$ significant at $5 \%$; ${ }^{* * *}$ significant at $1 \%$ (1-tail).

The binary regression result shows that board independence is significant and negatively related to audit quality ( $\alpha=-0.79, p<0.10$ ), which suggests that an increase in the independence of the board leads to a decrease in the quality of the audit. The result is at variance with prior studies (Adeyemi \& Fagbemi, 2010; O'Sullivan, 2000) that show a positive relationship between corporate governance and audit quality. Despite the variance with prior studies, our result can be explained with the premise of the agency theory that stipulates that as a fall out of the separation between ownership and control, management in the event of an opportunity, would go after their own benefits at the expense of the desires of shareholders (Jensen \& Meckling, 1976). Hence, by having non-executive directors the managers opportunistic behaviour can be checked (Fama \& Jensen, 1983). Abidin et al. (2009) opine that independent non-executive directors possess diverse background, attributes, characteristics and expertise, which improves board processes and decision-making and may play a vital role in the long term performance of the company. Also, Ajibolade \& Uwuigbe (2013) posit that the outside directors are likely to be concerned about their image and reputation in the public view and would be inclined towards ensuring quality financial reporting. Further, A possible explanation is that board independence which is a proxy for good corporate governance serves as a monitoring mechanism in the firm ensuring quality financial reporting hence it reduces the need for a high quality audit proxy by the engagement of a big four auditor.

Further the binary regression result shows an insignificant relationship between leverage and big four auditor $(\alpha=0.02, p>0.10)$, this implies that the 
debt-equity make-up of the firm has no relationship with the quality of the audit. Lastly, the result showed a positive relationship for both profitability ( $\alpha=1.29, p$ $<0.10)$ and firm size $(\alpha=-0.76, p<0.01)$ on audit quality. The result for firm size agrees with the study of Adeyemi \& Fagbemi (2010) that also found a positive relationship between firm size and audit quality. An explanation for this is that large firms usually have a large volume of operations and would require a big four auditor having the capacity to attend to such voluminous transactions in record time.

\section{Conclusion}

The study sets out to examine the relationship between corporate governance and audit quality in Nigeria; Drawing on evidence from previous studies and agency theory. We find board independence which was used as a proxy for corporate governance negatively related to audit quality which differs from a number of prior studies, although the result is in tandem with the premise of agency theory that an independent board which invariably means strong corporate governance in place will substitute for the need for a big four auditor our proxy for audit quality in the firm. The findings of the study have implications for organisational stakeholders, particularly; investors, managers, shareholders, policy makers and researchers. It highlights the importance of having a proper mix of competences on the board. It is also important for policy makers concerned about creating a vibrant corporate governance environment. The study recommends that the composition of non-executive directors as members of the board should be sustained and improved upon. The study also has implication for research. It expands the current literature on corporate governance and audit quality in $\mathrm{Ni}$ geria. While this study has contributed on several grounds, it has its limitations; only one corporate governance measure was used. It is recommended that future studies can employ other corporate governance mechanisms or perhaps develop an index comprising several variables to test the effect on audit quality.

\section{Conflicts of Interest}

The authors declare no conflicts of interest regarding the publication of this paper.

\section{References}

Abdullah, W. Z., Ismail, S., \& Jamaluddin, N. (2008). The Impact of Board Composition, Ownership and CEO Duality: The Malaysian Evidence. Malaysian Accounting Review, 7, 17-28

Abidin, Z. Z., Kamal, N. M., \& Jusoff, K. (2009). Board Structure and Corporate Performance in Malaysia. International Journal of Economics and Finance, 1, 150-164. https://doi.org/10.5539/ijef.v1n1p150

Adeyemi, S. B., \& Fagbemi, T. O. (2010). Audit Quality, Corporate Governance and Firm Characteristics in Nigeria. International Journal of Business and Management, 5, 169-179. https://doi.org/10.5539/ijbm.v5n5p169

Adeyemi, S. B., Okpala, O., \& Dabor, E. L. (2012). Factors Affecting Audit Quality in Ni- 
geria. International Journal of Business and Social Science, 3, 198-209.

Ajibolade, S. O., \& Uwuigbe, U. (2013). Effects of Corporate Governance on Corporate Social and Environmental Disclosure among Listed Firms in Nigeria. European Journal of Business and Social Sciences, 2, 76-92.

Akinjobi, A., \& Omowumi, O. (2010). The Changing Responsibilities of Auditors in Detection and Prevention of Business Frauds within a Challenging Environment in Nigeria. Journal of Emerging Trends in Economics and Management Sciences, 1, 71-75.

Amran, N. A., \& Che Ahmad, A. (2009). Family Business, Board Dynamics and Firm Value: Evidence from Malaysia. Journal of Financial Reporting and Accounting, 7, 53-74. https://doi.org/10.1108/19852510980000641

Amran, N. A., \& Che Ahmad, A. (2010). Family Succession and Firm Performance among Malaysian Companies. International Journal of Business and Social Science, 1, 193-203. https://doi.org/10.17576/ajag-2011-2-6538

Barbara, A., Brody, R., \& Pany, K. (2006). Findings on the Effects of Audit Firm Rotation on the Audit Process under Varying Strengths of Corporate Governance. Advances in Accounting, 22, 1-27. https://doi.org/10.1016/S0882-6110(06)22001-7

Chan, D., \& Wong, K. (2002). Scope of Auditors' Liability, Audit Quality, and Capital Investment. Review of Accounting Studies, 7, 97-122. https://doi.org/10.1023/A:1017983614986

Che-Ahmad, A., \& Osazuwa, N. P. (2015). Eco-Efficiency and Firm Value of Malaysian Firms. International Journal of Managerial and Financial Accounting, 7, 235-245. https://doi.org/10.1504/IJMFA.2015.074902

Che-Ahmad, A., Ishak, Z., \& Abd Manaf, N. A. (2003). Corporate Governance, Ownership Structure and Corporate Diversification: Evidence from the Malaysian Listed Companies. Asian Academy of Management Journal, 8, 67-89.

DeAngelo, L. E. (1981). Auditor Size and Audit Quality. Journal of Accounting and Economics, 3, 183-199. https://doi.org/10.1016/0165-4101(81)90002-1

Enofe, A. O., Mgbame, C., Aderin, A., \& Ehi-Oshio, O. U. (2013). Determinants of Audit Quality in the Nigerian Business Environment. Research Journal of Finance and Accounting, 4, 36-43.

Fama, E. F. (1980). Agency Problems and the Theory of the Firm. Journal of Political Economy, 88, 288-307. https://doi.org/10.1086/260866

Fama, E. F., \& Jensen, M. C. (1983). Separation of Ownership and Control. Journal of Law and Economics, 26, 301-325. https://doi.org/10.1086/467037

Greene, W. H. (2002). Econometric Analysis. London: Pearson Education.

Gujarati, D. N. (2003). Basic Econometrics (4th ed.). New York: McGraw Hill.

Gupta, S., \& Newberry, K. (1997). Determinants of the Variability in Corporate Effective Tax Rates: Evidence from Longitudinal Data. Journal of Accounting and Public Policy, 16, 1-34. https://doi.org/10.1016/S0278-4254(96)00055-5

Hosseinniakani, M. S., Inacio, H., \& Mota, R. (2014). A Review on Audit Quality Factors. International Journal of Academic Research in Accounting, Finance and Management Sciences, 4, 243-254.

Jackson, A. B., Moldrich, M., \& Roebuck, P. (2007). Mandatory Audit Firm Rotation and Audit Quality. Managerial Auditing Journal, 23, 420-437.

https://doi.org/10.2139/ssrn.1000076

Jensen, M. C., \& Meckling, W. H. (1976). Theory of the Firm: Managerial Behavior, Agency Costs and Ownership Structure. Journal of Financial Economics, 3, 305-360. https://doi.org/10.1016/0304-405X(76)90026-X 
Kota, H. B., \& Tomar, S. (2010). Corporate Governance Practices in Indian Firms. Journal of Management and Organization, 16, 266-279. https://doi.org/10.5172/jmo.16.2.266

Li, L., \& Song, F. M. (2013). Do Bank Regulations Affect Board Independence? A Cross-Country Analysis. Journal of Banking \& Finance, 37, 2714-2732. https://doi.org/10.1016/j.jbankfin.2013.03.026

Mgbame, C. O., Eragbhe, E., \& Osazuwa, N. P. (2012). Audit Partner Tenure and Audit Quality: An Empirical Analysis. European Journal of Business and Management, 4, 154-162.

Millichamp, A. H. (1994). Auditing: An Instructional Manual for Accounting Students (6th ed.). London: DP Publication.

O'sullivan, N. (2000). The Impact of Board Composition and Ownership on Audit Quality: Evidence from Large UK Companies. The British Accounting Review, 32, 397-414. https://doi.org/10.1006/bare.2000.0139

Omoye, A. S., \& Aronmwan, E. J. (2013). Audit Firm Rotation and Audit Quality in the Nigerian-Banking Sector. Benin Journal of Social Sciences, 21, 34-43.

Onwuchekwa, J. C., Erah, D. O., \& Izedonmi, F. (2012). Mandatory Audit Rotation and Audit Quality: Survey of Southern Nigeria. Research Journal of Finance and Accounting, 3, 70-77.

Palmrose, Z. V. (1988). 1987 Competitive Manuscript Co-Winner: An Analysis of Auditor Litigation and Audit Service Quality. Accounting Review, 63, 55-73.

Richardson, G., \& Lanis, R. (2007). Determinants of the Variability in Corporate Effective Tax Rates and Tax Reform: Evidence from Australia. Journal of Accounting and Public Policy, 26, 689-704. https://doi.org/10.1016/j.jaccpubpol.2007.10.003

Richardson, G., Lanis, R., \& Taylor, G. (2015). Financial Distress, outside Directors and Corporate Tax Aggressiveness Spanning the Global Financial Crisis: An Empirical Analysis. Journal of Banking and Finance, 52, 112-129. https://doi.org/10.1016/j.jbankfin.2014.11.013

Rittenberg, L. E., Johnstone, K., \& Gramling, A. (2012). Auditing: A Business Risk Approach (8th ed.). Boston, MA: Cengage.

Rossouw, G. J. (2005). Business Ethics and Corporate Governance in Africa. Business \& Society, 44, 94-106. https://doi.org/10.1177/0007650305274851

Salleh, Z., Stewart, J., \& Manson, S. (2006). The Impact of Board Composition and Ethnicity on Audit Quality: Evidence from Malaysian Companies. Malaysian Accounting Review, 5, 61-83.

Securities and Exchange Commission (2000). Revision of the Commission's Auditor Independence Requirements (Releases No. 33-79919). Washington DC: Author.

Ujunwa, A., Salami, P. O., \& Umar, A. H. (2013). CEO Duality and Firm Performance: An Integration of Institutional Perceptive with Agency Theory. International Journal of Social, Management, Economics and Business Engineering, 7, 97-103.

Wan Hussin, W. N., Che-Adam, N., Lode, N. A., \& Kamardin, H. (2005). Determinants of Early Adoption of FRS 114 (Segment Reporting) in Malaysia. Asian Academy of Management Journal, 10, 1-20. 